\title{
Length-weight relationship in ten fish species from the Nhamundá River, the Amazon Basin, Brazil
}

\author{
Tiago Magalhães da Silva FREITAS ${ }^{1 *}$, Joao Batista de Souza e SOUZA ${ }^{1}$, Bruno da Silveira PRUDENTE², \\ Luciano Fogaça de Assis MONTAG² \\ 1 Universidade Federal do Pará, Campus Universitário do Marajó-Breves, Faculdade de Ciências Naturais. Conjunto Bandeirante, bairro Aeroporto, 68800-000 Breves, PA, Brasil. \\ 2 Universidade Federal do Pará (UFPA), Laboratório de Ecologia e Conservação, Instituto de Ciências Biológicas, Rua Augusto Corrêa, 01, Guamá, 66.075-110, Belém, PA, Brasil \\ * Corresponding author: freitastms@gmail.com
}

\section{ABSTRACT}

Studies on the length-weight relationship (LWR) of fishes are an important tool to describe several biological aspects of the species. Consequently, these studies are relevant due the necessity of comprehension about fish life cycle. Thus, this study aimed to establish the length-weight relationship of the ten most common fish in the Lower Nhamundá River, left tributary of the Amazon River. The capture of fish was conducted in January 2008 using gill nets. A total of 807 individuals, ten species and three Orders (Characiformes, Siluriformes and Clupeiformes) were analyzed. The parameter $b$ varied from 2.680 to 3.698. The LWR were shown for the first time for two species: Anostomoides laticeps and Ageneiosus polystictus. Finally, this research emphasizes the importance of LWR studies in the Amazon and the use of primary data for fisheries management plans.

KEYWORDS: growth pattern, alometry, fish, Amazonia.

\section{Relação peso-comprimento de dez espécies de peixes do Rio Nhamundá, Bacia Amazônica, Brasil}

\section{RESUMO}

Estudos acerca da relação peso-comprimento em peixes são importantes ferramentas para descrever diversos aspetos biológicos das espécies. Consequentemente, estes estudos são importantes em decorrência da necessidade de compreensão do ciclo de vida dos peixes. Sendo assim, este estudo visou estabelecer a relação peso-comprimento de dez espécies mais comuns de peixes na regiẫo do baixo Rio Nhamundá, afluente da margem esquerda do Rio Amazonas. A captura dos peixes foi realizada em janeiro de 2008, utilizando redes de emalhar. Foram analisados 807 indivíduos, pertencentes a dez espécies e três Ordens (Characiformes, Siruliformes e Clupeiformes). O coeficiente alométrico "b" variou de 2,680 à 3,698. A relação peso-comprimento é apresentada pela primeira vez para duas espécies: Anostomoides laticeps e Ageneiosus polystictus. Por fim, esse estudo enfatiza a importância de estudos de relação peso-comprimento de peixes na Amazônia e o uso de dados primários para fins conservacionistas.

PALAVRAS-CHAVE: padrão de crescimento, alometria, peixe, Amazônia. 
Studies of the length-weight relationship (LWR) of fishes were performed since the late 19th century, and are an important tool to describe several biological aspects (Le Cren 1951; Froese 2006). The LWR allows to 1) estimate fish weight based on length and vice versa, 2) analyze the growth pattern by the allometric coefficient of the analyzed species, and 3) obtain the body conditions of the sampled fish specimens (i.e. fat storage or gonadal development etc.) (Froese 2006). Additionally, the knowledge from LWR is essential to assess fish stocks, fisheries, and environmental monitoring programs (Froese et al. 2011; Giarrizzo et al. 2015). According to Freitas et al. (2014), the LWR studies become relevant due the need to comprehend the fish lifecycle, principally regions where fisheries represent one of the most important economic activities and fish stocks are the main food source for many traditional communities.

The Amazon Basin has the largest fish diversity on Earth (Albert and Reis 2011), but there are few studies concerning the fish LWR in this region (Freitas et al. 2014; Giarrizzo et al. 2015; Schmid et al. 2015). Due the high environmental heterogeneity of the Amazon Basin (Junk and Furch 1993), the wide-ranged species have to improve different life strategies, which may reflect variances in the biological parameters, such as those obtained from LWR studies. Consequently, these knowledges will be important to local management and conservation policies of these species. Thus, this study presents information about the LWR of common fish species from the Lower Nhamundá River, in a protected area in the Central Amazon, Brazil.

The samplings were carried out in the Lower Nhamundá River (Figure 1), left tributary of the Amazon River (Central Amazon, Brazil), dividing Pará and Amazonas States (1'42'25”S, 52 $\left.17^{\prime} 35^{\prime \prime} \mathrm{W}\right)$. This stretch is characterized as a clear water river and a lowland amazon rainforest, nearly 40 meters above the sea level, and is located at the Floresta Estadual de Faro (State Forest of Faro), one of the five conservation units forming the northern mosaic of the Amazon River in the State of Pará (Ávila-Pires et al. 2010).

Fishes were collected in January 2008, using gillnets (mesh size: 2, 4, 6, 8, 10, 12 and $18 \mathrm{~cm}$, opposite knots), and processed in the field, measured to the nearest centimeter (standard length, Ls) and weighted to the nearest gram (total weight, W). Voucher specimens were deposited at the ichthyology collection of the Museu Paraense Emilio Goeldi MPEG (Pará, Brazil) under the codes: MPEG 14764-14769, MPEG 14776-14780, MPEG 14785-14795, MPEG 14800, MPEG 14859, MPEG 14863, and MPEG 14866-14871. All scientific names, authorship, and years of description were checked in FishBase (Froese and Pauly 2016).

The LWR was estimated following the model first proposed by Järvi (1920; see Froese 2006): $W=a^{*} L s^{b}$, which

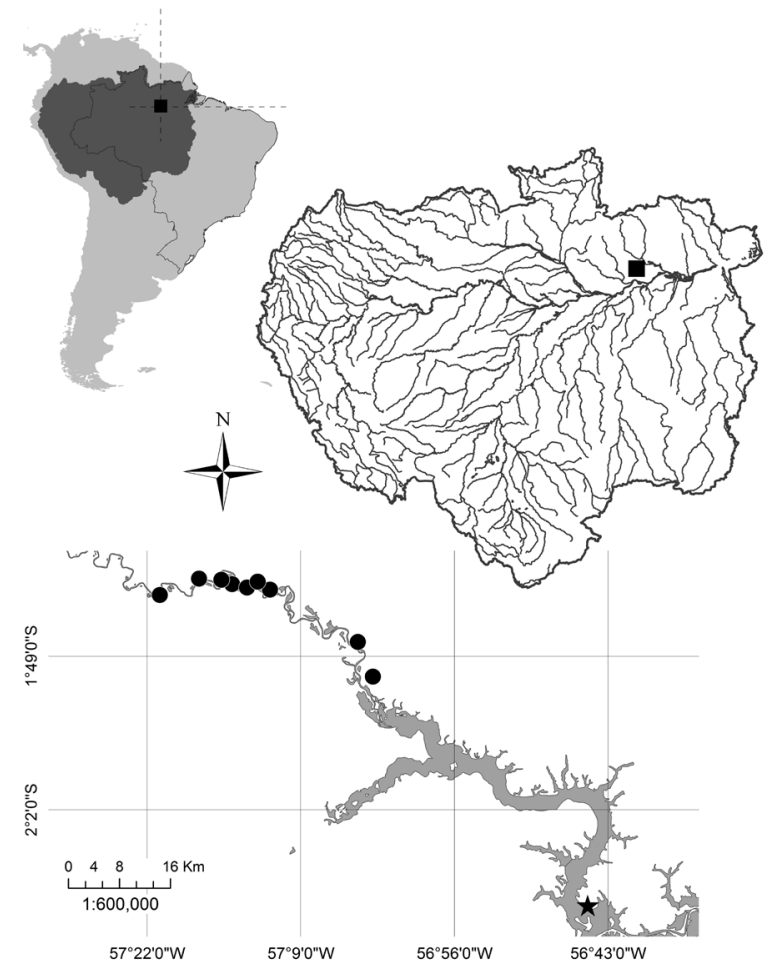

Figure 1 - Sampling area in the Nhamundá River, Amazon Basin, Brazil. Black spots can represent more than one collection site. Black star represents the city of Faro (State of Pará).

considers that the relative body proportions of the fishes increase according to the coefficient of proportionality $(a)$ and by the coefficient of allometry (b). The LWRs were determined using a non-linear regression routine, after the exclusion of outliers identified graphically by plotting Ls vs W measurements (Froese and Binohlan 2000). The LWR was applied in fish species with at least 15 individuals.

A total of 807 specimens representing ten different species belonging to seven Families and three Orders were analyzed. The best-represented Order was Characiformes (six species), followed by Siluriformes (three species) and Clupeiformes (one species). Table 1 summarizes the data concerning sample size, minimum and maximum length, and weight for each species, the parameters of the LWR with confidence intervals (95\%), and, for comparison purpose, available information from the literature.

The allometric coefficient $b$ varied from 2.680 for Anostomoides laticeps, to 3.698 for Boulengerella maculata. According to the parameter $b$, the species $A$. polystictus had an isometric growth pattern $(b-3)$. Negative alometry $(b$ <3) was recognized for $A$. laticeps, A. halecinus, T. albus, $A$. nuchalis and I. amazonica; whereas A. microlepis, B. maculata, 
Table 1. Length-weight relationships of dominant fish species, Lower Nhamundá River, State of Pará, Brazil. Sample size (N), length and weight range are by species; estimated $a$ and $b$ values with confidence limits $(95 \%)$, determination coefficient $\left(\mathrm{R}^{2}\right)$, and published $a$ and $b$ values.

\begin{tabular}{|c|c|c|c|c|c|c|c|c|c|}
\hline \multirow{2}{*}{$\begin{array}{l}\text { ORDER/Famíly/ } \\
\text { Species }\end{array}$} & \multirow{2}{*}{$\mathrm{N}$} & \multirow{2}{*}{ Length range $(\mathrm{cm})$} & \multirow{2}{*}{$\begin{array}{l}\text { Weight } \\
\text { range }(\mathrm{g})\end{array}$} & \multicolumn{2}{|c|}{ Estimated parameters } & \multirow{2}{*}{$\mathrm{R}^{2}$} & \multicolumn{2}{|c|}{ Published values } & \multirow{2}{*}{ Source } \\
\hline & & & & a (95\% CL) & $b(95 \% \mathrm{CL})$ & & a & $b$ & \\
\hline \multicolumn{10}{|l|}{ CHARACIFORMES } \\
\hline \multicolumn{10}{|l|}{ Acestrorhynchydae } \\
\hline $\begin{array}{l}\text { Acestrorhynchus } \\
\text { microlepis } \\
\text { (Jardine 1841) }\end{array}$ & 43 & $11.5-21.5$ & $22-117$ & $\begin{array}{c}0.008 \\
(0.0012-0.0141)\end{array}$ & $\begin{array}{c}3.121 \\
(2.837-3.405)\end{array}$ & 0.941 & $0.0071-0.0255$ & $2.66-3.37$ & $\begin{array}{l}\text { Freitas et al. } \\
(2014) \\
\text { Froese and } \\
\text { Pauly (2016) } \\
\text { Giarizzo et al. } \\
(2011 ; 2015)\end{array}$ \\
\hline \multicolumn{10}{|l|}{ Anostomidae } \\
\hline $\begin{array}{l}\text { Anostomoides } \\
\text { laticeps } \\
\text { (Eigenmann 1912) }\end{array}$ & 29 & $19-25$ & $118-275$ & $\begin{array}{c}0.061 \\
(0.0213-0.1369)\end{array}$ & $\begin{array}{c}2.680 \\
(2.185-3.175)\end{array}$ & 0.912 & $0.0060-0.0288$ & $2.84-3.22$ & $\begin{array}{c}\text { Froese and } \\
\text { Pauly (2016) }\end{array}$ \\
\hline \multicolumn{10}{|l|}{ Ctenolucidae } \\
\hline $\begin{array}{l}\text { Boulengerella } \\
\text { maculata } \\
\text { (Valenciennes } \\
1850 \text { ) }\end{array}$ & 39 & $24.5-38.5$ & $83-410$ & $\begin{array}{c}0.001 \\
(0.0008-0.0012)\end{array}$ & $\begin{array}{c}3.698 \\
(3.341-4.043)\end{array}$ & 0.950 & $0.0005-0.0012$ & $3.36-3.61$ & $\begin{array}{l}\text { Giarizzo et al. } \\
\quad(2011)\end{array}$ \\
\hline \multicolumn{10}{|l|}{ Hemiodontidae } \\
\hline $\begin{array}{l}\text { Hemiodus im- } \\
\text { maculatus Kner } \\
1858\end{array}$ & 278 & $13-23$ & $32-183$ & $\begin{array}{c}0.012 \\
(0.0081-0.0159)\end{array}$ & $\begin{array}{c}3.140 \\
(2.047-3.223)\end{array}$ & 0.938 & $0.0016-0.0033$ & $3.32-3.56$ & $\begin{array}{l}\text { Giarizzo et al. } \\
\quad(2011)\end{array}$ \\
\hline \multicolumn{10}{|l|}{ Triportheidae } \\
\hline $\begin{array}{l}\text { Agoniates } \\
\text { halecinus Müller } \\
\text { and Troschel } 1845\end{array}$ & 147 & $13.5-20.5$ & $22-90$ & $\begin{array}{c}0.018 \\
(0.0101-0.0259)\end{array}$ & $\begin{array}{c}2.730 \\
(2.570-2.890)\end{array}$ & 0.907 & $0.0024-0.0411$ & $2.81-3.27$ & $\begin{array}{c}\text { Froese and } \\
\text { Pauly (2016) } \\
\text { Giarizzo et al. } \\
\quad(2015)\end{array}$ \\
\hline $\begin{array}{l}\text { Triportheus albus } \\
\text { Cope } 1872\end{array}$ & 81 & $13-18$ & $32-74$ & $\begin{array}{c}0.031 \\
(0.0171-0.0489)\end{array}$ & $\begin{array}{c}2.690 \\
(2.502-2.878)\end{array}$ & 0.900 & $0.0049-0.0532$ & $2.46-3.22$ & $\begin{array}{l}\text { Freitas et al. } \\
(2014) \\
\text { Froese and } \\
\text { Pauly (2016) } \\
\text { Giarizzo et al. } \\
\quad(2015)\end{array}$ \\
\hline \multicolumn{10}{|l|}{ SILURIFORMES } \\
\hline \multicolumn{10}{|l|}{ Auchenipteridae } \\
\hline $\begin{array}{l}\text { Ageneiosus } \\
\text { polystictus } \\
\text { Steindachner } 1915\end{array}$ & 20 & $19-44$ & $\begin{array}{l}107- \\
1235\end{array}$ & $\begin{array}{c}0.011 \\
(0.0046-0.0184)\end{array}$ & $\begin{array}{c}3.072 \\
(2.895-3.249)\end{array}$ & 0.987 & $0.0020-0.0118$ & $2.92-3.36$ & $\begin{array}{l}\text { Froese and } \\
\text { Pauly (2016) }\end{array}$ \\
\hline $\begin{array}{l}\text { Auchenipterichthys } \\
\text { Iongimanus } \\
\text { (Günther 1864) }\end{array}$ & 104 & $8.5-16.5$ & $14-97$ & $\begin{array}{c}0.013 \\
(0.0070-0.0200)\end{array}$ & $\begin{array}{c}3.210 \\
(3.019-3.404)\end{array}$ & 0.924 & $0.0024-0.0420$ & $2.47-3.22$ & $\begin{array}{l}\text { Giarizzo et al. } \\
\quad(2011) \\
\text { Freitas et al. } \\
(2014)\end{array}$ \\
\hline $\begin{array}{l}\text { Auchenipterus } \\
\text { nuchalis (Spix and } \\
\text { Agassiz 1829) }\end{array}$ & 51 & $10.5-18.5$ & $19-75$ & $\begin{array}{c}0.034 \\
(0.0199-0.0491)\end{array}$ & $\begin{array}{c}2.661 \\
(2.500-2.823)\end{array}$ & 0.949 & $0.0032-0.0149$ & $2.72-3.32$ & $\begin{array}{c}\text { Froese and } \\
\text { Pauly (2016) } \\
\text { Giarizzo et al. } \\
(2015)\end{array}$ \\
\hline \multicolumn{10}{|l|}{ CLUPEIFORMES } \\
\hline \multicolumn{10}{|l|}{ Pristigasteridae } \\
\hline $\begin{array}{l}\text { Ilisha amazonica } \\
\text { (Miranda Ribeiro } \\
\text { 1920) }\end{array}$ & 15 & $14.5-18$ & $41-76$ & $\begin{array}{c}0.037 \\
(0.0083-0.0927)\end{array}$ & $\begin{array}{c}2.622 \\
(2.086-3.159)\end{array}$ & 0.888 & $0.0253-0.0481$ & $2.39-3.24$ & $\begin{array}{c}\text { Froese and } \\
\text { Pauly (2016) } \\
\text { Giarizzo et al. } \\
(2011)\end{array}$ \\
\hline
\end{tabular}


H. immaculatus and A. longimanus had a positive allometric growth $(b>3)$.

Considering the confidence intervals of the growth patterns, all analyzed species corroborate with the expected values of the allometric coefficient $b(2.5-3.5)$ as defined by Froese (2006), except for B. maculata $(b=3.698)$. The alometric growth factor $(b)$ obtained for $A$. microlepis, $B$. maculata, A. halecinus, T. albus, A. longimanus, $A$. nuchalis and $I$. amazonica ranged the same value range that already described by literature (Giarrizzo et al. 2011, Freitas et al. 2014, Giarrizzo et al. 2015). For H. immaculatus we recorded an isometric growth, while Giarrizzo et al. (2011) verified a positive alometry for the specie. Although the $b$ values for $A$. laticeps and $A$. polystictus can be found at Fishbase website, the values were not obtained with primarily length-weight data of these species. The values were estimated using an innovative methodology proposed by Froese et al. (2014), based on LWR data of closest taxon and a Bayesian approach.

As already observed by Fulton (1904) in one of the early studies with LWR, and by other current studies (Karakulak et al. 2006; Fontoura et al. 2010), the growth pattern (b) within the same species can be changeable, depending on the season, food availability, population, sex, environmental conditions or physiology. Since each place has its environmental peculiarity and the corresponding fauna, this study emphasizes the importance of amplifying the biological knowledge of the species distribution, improving conservation actions and management plans.

Finally, this research emphasizes the importance of LWR studies in the Amazon and the use of primary data for fisheries management plans, since different environment conditions result different lifecycle parameters in the same species. This may allow more sustainable fishery exploitation and increase the probability of non-exhaustion of natural populations of fish in the region.

\section{ACKNOWLEDGEMENTS}

The authors thank Conservaçáo Internacional (CI-Brazil) and mining company Rio Tinto for financing the project "Diagnóstico da biodiversidade das unidades de conservaçáo estaduais do mosaico 'Calha Norte', Estado do Pará", from where these data were obtained. We would like to thank, in the person of Marina B. Mendonça, all of who participated in the fieldwork, and to Dr. Daniel de Paiva Silva for the English review.

\section{REFERENCES}

Albert, J.S.; Reis, R.E. 2011. Historical Biogeography of Neotropical Freshwater Fishes. University of California Press, California, 408p.
Ávila-Pires, T.C.S.; Hoogmoed, M.S.; Rocha, W.A. 2010. Notes on the Vertebrates of northern Pará, Brazil: a forgotten part of the Guianan Region, I. Herpetofauna. Boletim do Museu Paraense Emílio Goeldi. Ciências Naturais, 5: 13-112.

Fontoura, N.F.; Jesus, A.S.; Larre, G.G.; Porto, J.R. 2010. Can weight/length relationship predict size at first maturity? A case study with two species of Characidae. Neotropical Ichthyology, 8: 835-840.

Freitas, T.M.S.; Prudente, B.S.; Fontoura, N.F.; Montag, L.F.A. 2014. Length-weight relationships of dominant fish species from Caxiuanã National Forest, Eastern Amazon, Brazil. Journal of Applied Ichthyology, 30: 1081-1083.

Froese, R. 2006. Cube law, condition factor and weight-length relationships: history, meta-analysis and recommendations. Journal of Applied Ichthyology, 22: 241-253.

Froese, R.; Binohlan, C. 2000. Empirical relationships to estimate asymptotic length, length at first maturity and length at maximum yield per recruit in fishes, with a simple method to evaluate length frequency data. Journal of Applied Ichthyology, 56: 758-773.

Froese, R.; Pauly, D. 2016. Fishbase. World Wide Web electronic publication. Available at: http://www.fishbase.org. (accessed on 20 June 2016).

Froese, R.; Thorson, J.T.; Reyes Jr, R.B. 2014. A Bayesian approach for estimating length-weight relationships in fishes. Journal of Applied Ichthyology, 30: 78-85.

Froese, R.; Tsikliras, A.C.; Stergiou, K.I. 2011. Editorial note on weight-length relations of fishes. Acta Ichthyologica Et Piscatoria, 41: 261-263.

Fulton, T.W. 1904. The rate of growth of fishes. The rate of growth of fishes. 22nd Annual Report of the Fishery Board of Scotland, 3: $141-241$

Giarrizzo, T.; Bastos, D.; Andrade, M. 2011. Length-weight relationships for selected 177 fish species of Rio Trombetas Biological Reserve: a reference study for the 178 Amazonian basin. Journal of Applied Ichthyology, 27: 1-3.

Giarrizzo, T.; Oliveira, R.R.S.; Andrade, M.C.; Gonçalves, A.P.; Barbosa, T.A.P.; Martins, A.R.; et al. 2015. Length-weight and length-length relationships for 135 fish species from the Xingu River (Amazon Basin, Brazil). Journal of Applied Ichthyology, 31: 415-424.

Järvi, T.H. 1920. Die kleine Marane (Coregonus albula L.) im Kei-telesee, eine okologische und okonomische Studie. Annales Academiae Scientiarum Fennicae, Helsinki, 302p.

Junk W.J; Furch K. 1993. A general review of tropical South American floodplains. Wetlands Ecology and Management, 2: 231-238.

Karakulak, F.S.; Erk, H.; Bilgin, B. 2006. Length-weight relationships for 47 coastal fish species from the northern Aegean Sea, Turkey. Journal of Applied Ichthyology, 22 274-278.

Le Cren, E.D. 1951. The length-weight relationship and seasonal cycle in gonad weight and condition in the perch (Perca fluviatilis). Journal of Animal Ecology, 20: 201-219.

Schmid, K.; Andrade, M.C.; Jesus, A.J.S.; Araujo, J.S.; Santos, P.R.B.; Giarrizzo, T. 2015. Length-Weight Relationships for Fish Fauna from Waterbodies in the Upper Tapajós River Basin of Palito Mountain Ridge, Brazilian Amazon Region. Biota Amazônica, 5: 112-114.

Received: 04/05/2016

Accepted: 17/08/2016 